\title{
TEACHERS' VOICES ON THE CHALLENGES OF THE IMPLEMENTATION OF COMMUNICATIVE APPROACH IN REGARDS TO THE 2013 CURRICULUM
}

\author{
Yenny Rahmawati \\ Syarif Hidayatullah State Islamic University of Jakarta, Indonesia \\ (yenny@uinjkt.ac.id)
}

Received: $8^{\text {th }}$ March 2019; Revised: $7^{\text {th }}$ May 2019; Accepted: $28^{\text {th }}$ June 2019

\begin{abstract}
The Indonesian ELT current curriculum (the 2013 Curriculum) adopts communicative Approach (CA) as its basis foundation. Despite the fact that this approach has been adopted for some years, some research studies showed that it does not bring any significant improvement to the learner's outcome. There are several reasons underpinning the failures of the implementation of CA in regards to the 2013 curriculum. This study is, therefore, aimed at investigating the EFL Indonesian teachers' perspectives on the challenges they faced in the implementation of communicative approach in their classrooms along with the 2013 curriculum. Four participants were involved in this study that were given questionnaires and interviewed for data collection. Qualitative design by case study was used in this study and the results indicated that all teachers in this study encountered challenges when implementing the concept of CA along with the 2013 curriculum, i.e. students' low motivations, the teachers' role, the class size, the teachers' income, and the availability of English materials.
\end{abstract}

Key Words: communicative approach; teachers' perception; challenges; 2013 curriculum

\section{ABSTRAK}

Kurikulum Bahasa Inggrisdi Indonesia saat ini (Kurikulum 2013) mengadopsi Pendekatan Komunikatif (CA) sebagai landasan dasarnya. Terlepas dari kenyataan bahwa pendekatan ini telah diadopsi selama beberapa tahun, beberapa penelitian menunjukkan bahwa Pendekatan Komunikatif tidak membawa dampak yang signifikan terhadap hasil pelajar. Ada beberapa alasan yang mendasari kegagalan implementasi CA tersebut terkait kurikulum 2013. Oleh karena itu, penelitian ini bertujuan mengeksplorasi perspektif guru bahasa Inggris di Indonesia tentang tantangan yang mereka hadapi dalam menerapkan pendekatan komunikatif di ruang kelas mereka dalam kerangka kurikulum 2013. Empat peserta terlibat dalam penelitian ini yang diberi kuesioner dan diwawancarai untuk pengumpulan data. Penelitian ini menggunakan desain kualitatif dengan studi kasus dan hasilnya menunjukkan bahwa semua guru dalam penelitian ini menghadapi tantangan ketika menerapkan konsep CA bersama dengan kurikulum 2013, yaitu motivasi siswa, peran guru, 'konten asing', dan ketersediaan materi bahasa Inggris.

Kata Kunci: pendekatan komunikatif; persepsi guru; tantangan; kurikulum 2013

How to Cite: Rahmawati, Y. (2019). Teachers' Voices on the Challenges of the Implementation of Communicative Approach in Regards to the 2013 Curriculum. IJEE (Indonesian Journal of English Education), 6(1), 65-78. doi:10.15408/ijee.v6i1.12761

IJEE (Indonesian Journal of English Education), 6 (1), 2019, 65-78

P-ISSN: 2356-1777, E-ISSN: 2443-0390 | DOI: http://doi.org/10.15408/ijee.v6i1.12761

This is an open access article under CC-BY-SA license (https://creativecommons.org/licenses/by-sa/4.0/) 


\section{INTRODUCTION}

The development of English as a global language has strengthened its position as a lingua franca. As a consequence, most countries in the world - especially non-English speaking countries - consider English as an important language to be learnt. This condition impacts on the educational system in many countries; some have English as a medium of instruction, while others have English as a compulsory subject at school.

Where English is a second or a foreign language in their counties, many teachers try to adopt teaching approaches suggested by the West. As Musthafa (2001) argues, English is believed to belong to the West, therefore the teaching approaches should be based on the 'owners' of the language. One of the most popular teaching approaches, CLT, is based on the understanding of what constitutes a goal which is widely adopted by teachers in Asian countries (Li, 2000).

The more current notion of communicative competence was first introduced by Hymes in the mid-1960s (Berns, 1990; Brown, 2007; Trosborg, 1986) and subsequently greatly influenced language teaching. Hymes (1979) states that communicative competence is interrelated with the knowledge of language and the ability to use that knowledge appropriately. He proposed the idea that "there are rules of use without which the rules of grammar would be useless" (1979, p.15). By this, he emphasized that there are other important elements to be mastered besides grammatical rules. Communicative competence sees language as a whole, not as an isolated system. It connects the language to the "nature of communication" (Trosborg, 1986, p.7). In addition, Canale (1983) stresses that "communicative competence refers both to knowledge and skills using this knowledge when interacting in actual communication" (p.5). In other words, competence does not only include grammatical competence but also social competence to interact with the community or culture.

Communicative competence has several components. These components were first specified by Canale and Swain (1980), later to be revised by Canale (1983). The first component is grammatical competence; this competence deals with the ability to know the form and meaning of the language, which involves the knowledge of grammar, spelling, pronunciation, and vocabulary. Second, the component of sociolinguistic competence includes the ability to use the linguistic competence properly in communication in different sociolinguistic contexts. The third 
component, discourse competence comprises the ability to integrate grammatical competence and meanings into oral and written form. Strategic competence, the fourth component is the ability to sustain conversation by using communication strategies such as risktaking, negotiating and reduction strategy. All of the aforementioned competencies are essential elements in communication. By knowing the context and the culture of the interlocutor, it would be easier to get into a conversation and to minimize misunderstandings during the conversation.

\section{Communicative}

Language Teaching (CLT) as the application of communicative competence in the classroom has also been accorded great attention from the educational world. I, once, thought that the approaches suggested by the West must be appropriate and suitable in every context. However, I found myself 'trapped' in the maze of myriad promotions of the concept. I tried to implement this concept in my classroom, but often found myself referring back to my 'traditional' method of teaching, which I believed my students were most comfortable with. As an example, at that time, I had my students work in groups, as CLT suggests that group work is beneficial in the classroom to achieve the intended learning objective (Richards, 2005). However, in my context it was hard to implement this concept. I had about 40 students in my class and grouping students was not easy. It took time to organise the group, and the classroom became very noisy. I found myself becoming frustrated at my vain attempts to make the students listen to me, and I also received a complaint from the teacher next door because of the noise. This is what Dardjowidjojo (1997, as cited in Jazadi 2004, p.4) called the "pragmatic constraint" that big classes have, which could prevent a teacher from performing well.

Since Indonesia got its independence, the educational curriculum has already changed for several times: (1) 1945's grammar translation-based curriculum, (2) 1958's Audio-lingual based-curriculum, 1975's revised Audio-lingual basedcurriculum, (4) 1984's structure-based communicative curriculum, (5) 1994's meaning-based communicative curriculum, (6) 2004's competencybased curriculum, (7) 2006 KTSP competency-based curriculum, 2013 Curriculum competency-based curriculum (Sahirudin, 2013).

The current ELT curriculum in Indonesian schools adopts Communicative curriculum which is actually similar to that of used in the 
previous ones. This curriculum is actually aimed at answering problems faced by the previous curriculum, which focuses on the competency-based curriculum with improving students' characters formation. The promotion of the concept of communicative through ELT materials has spread widely throughout the country. The popularity of this concept keeps increasing as many teachers apply the concepts in their classroom. However, the use of communicative approach has also brought some concerns for teachers in their classroom practice. Some problems are related to the readiness of Indonesian teachers to implement the concept (Suwandi \& Bharati, 2007), while others concern about teachers' lack of confidence, students' motivation, the lack of availability of authentic materials and the issues of authentic assessments (Dardjowidjojo, 2002; Musthafa, 2001).

In Indonesia, CLT is probably seen as appropriate to respond to the dissatisfaction of the previous methods. However, it appears that in practice the communicative approach has never really been applied. This is because the "guidelines given by the government were very structural" (Dardjowidjojo, 2000, p.25). A research study on English teachers in secondary schools in Java Island by Hamied (1997, as cited in Rudianto, 2007) indicates that only
$19.6 \%$ of teachers stated that they used the communicative approach. This is because the teachers encountered some constraints in the implementation, such as lack of facilities, students' ability and authentic materials.

Indonesia has experienced changes in relation to its national curriculum. The school curriculum is designed and developed centrally by the Ministry of National Education-Curriculum Centre of the Ministry's Office of Research and Development (Ministry of National Education Republic of Indonesia, 2003).

Since its independence, Indonesia has changed its curriculum seven times using three different approaches. Lie (2007) summarises the curriculum applied in Indonesia as follows table 1.

Table 1. Indonesian ELT Curriculum

\begin{tabular}{|c|c|c|}
\hline $\begin{array}{l}\text { Starting } \\
\text { year }\end{array}$ & $\begin{array}{ll}\text { Name of } \\
\text { curriculum }\end{array}$ & Approach \\
\hline 1945 & Unknown & $\begin{array}{l}\text { Grammar- } \\
\text { Translation }\end{array}$ \\
\hline 1968 & Oral Approach & Audio-Lingual \\
\hline 1975 & Oral Approach & Audio-Lingual \\
\hline 1984 & $\begin{array}{l}\text { Communicative } \\
\text { Approach }\end{array}$ & Communicative \\
\hline 1994 & $\begin{array}{l}\text { Meaning-Based } \\
\text { Curriculum }\end{array}$ & Communicative \\
\hline 2004 & $\begin{array}{l}\text { Competence- } \\
\text { Based Curriculum }\end{array}$ & Communicative \\
\hline 2006 & $\begin{array}{l}\text { KTSP (Kurrikulum } \\
\text { Tingkat Satuan } \\
\text { Pendidikan-The } \\
\text { School Level } \\
\text { Curriculum) }\end{array}$ & Communicative \\
\hline 2013 & 2013 Curriculum & Communicative \\
\hline
\end{tabular}


The latest curriculum is the 2013 Curriculum created as the development of KTSP and an answer of some dissatisfaction of the previous curricula, one of which is not answering the $21^{\text {st }}$ century needs or knowledge-based society. The competencies to achieve are spiritual, social, knowledge and skill. It is designed by the Ministry of National Education and Culture at the beginning of 2013 or in the Academic Year of 2013/2014. As one of the centralized curricula, this new curriculum tries to balance the hardskills and the soft-skills by using learning scientific approach aimed at producing productive, creative, innovative, and affective Indonesian people through the integration of knowledge, skills, and attitude (Paparan Wamendik, 2014). These integrations is based on the Indonesia rank at TIMSS (Trends in International Mathematics and Science Study) study and PISA (Program for International Student Assessment), in which in 2011 Indonesia only achieved level 3 out from the 6 levels in a cognitive area related to the level of critical thinking (2014).

However, the implementation of this centralized curriculum is problematic for some teachers. A research study conducted by Suparman (2007) in one secondary school in Lampung, Indonesia, reveals that the teachers in his research encountered a number of challenges in implementing this centralized curriculum. These challenges relate to (1) teachers' qualifications (some of the teachers had not graduated from an English education major), (2) teachers' understandings and knowledge of the curriculum, and (3) the teacher-student ratio, with only four teachers for 24 classes with 45-50 students in each class. In addition, Lie (2007, p.6-7) argues that "a one-size-fits-all curriculum would simply not work for the Indonesian setting". Indonesia is a big country with many different cultures. Therefore, one centralized curriculum will not fit all regions of Indonesia.

I believe some research have been conducted in Indonesia under the topic of CLT. However, I found it difficult to find these research studies, especially at the primary and university levels. This might be because research publication in Indonesia is still limited; on-line journals are also difficult to get. For this reason, I do not have any data related to the implementation of CLT at the primary and university levels. For these reasons, it is worthwhile to observe and analyze the practice of communicative approach in regards to the implementation of the 2013 curriculum seen from the teachers' perspectives. 


\section{METHOD}

This research aimed at revealing the challenges faced by the four English teachers (two females and two males) at secondary schools in Tangerang Selatan when implementing the concept of communicative approach along with the practice of the 2013 curriculum. The participants were selected on the criteria: 1) the teachers should have at least 2 years of experience of teaching EFL setting, 2) they indicated that they have experiences dealing with communicative approach in their classrooms, and 3) they should have willingness to get involved in the study.

This study is qualitative in nature by case study; the data were gained through interviews, and questionnaire. The questionnaire was used to gain a general understanding from the teachers about English teaching in Indonesia and the concept of CLT as well as to develop the interview questions. The questionnaire was divided into three parts with sixteen questions in total. Part 1 sought personal information. It consisted of six questions and was designed to gain general information about the participants' personal and educational background. Part 2 was designed to obtain the participants' perceptions toward CLT. The participants were asked to put a tick(s) in the appropriate column(s) that corresponded to their answers and to write comments regarding the answers. Part 3 contains open-ended questions and was designed to further explore the participants' perceptions of ELT and the concept of CLT.

Nineteen questions were generated for the interviews. All of the interviews were then transcribed in preparation for identifying descriptive data and conducting analysis. The places of interviews were chosen by the participants themselves, and the interviews were audio-taped. Each interview took about one hour perparticipant. In these interviews, I allowed my participants to choose whether the interviews would be conducted in English or in Bahasa Indonesia. The main reasons I gave them this choice were to give the participants the freedom to choose the language they felt most comfortable with and to reduce the language barrier in conveying the meaning.

After in-depth interviews had been conducted, all data were transcribed for analysis. While reading all the data, subthemes were created corresponding to the research questions. In this process, the data were modified and reduced the potential subthemes until similar general subthemes that conformed to the research questions 
were found. The data from the questionnaire and interviews were used to triangulate the findings. In addition, extracts from the questionnaire and interviews were used to support the findings.

\section{FINDINGS AND DISCUSSIONS}

There are several challenges in the implementation of the communicative approach along with the practice of the 2013 curriculum. All the teachers in the study share similar ideas on the problems they faced.

\section{Students' motivations}

The data revealed that all teachers in the study were concerned with their students' motivation in learning English. They mentioned that the students often had low motivation in learning English.

The students are not motivated to memorize the vocabulary and to learn English... (Teacher A, public Junior high School)

It is really hard to give them motivation... most of them come to the English class because there is a schedule for that. (Teacher B, private Junior high school)

They do not participate [in the discussion] because some of them have low motivation to learn English. (Teacher C)
The teachers explained that most students seem to lack the awareness of the importance of English. This might be caused by the status of English as a foreign language in the country. They stated that, as a foreign language, English was a compulsory subject and was tested in the examination; it appears that the students learned English for these purposes only. This perception is similar to what has been explained by some researchers (Li, 2000; Segovia \& Hardison, 2009; Yu, 2004), who contend that their students lack interest in learning English as it is not their language.

Furthermore, Dardjowidjojo (2002, p.123) identifies the reason for some Indonesian students having low motivation in learning English as being because "they learn English because they have to, not because they want to". In fact, in most areas in Indonesia, English is considered as a difficult subject - even more difficult than Maths. Due to the above reasons, many students tend to lack the motivation to learn English.

As a consequence of being a foreign language in Indonesia, English is rarely used for daily needs (Musthafa, 2001). Bahasa Indonesia has a strong position as it is used as a national and official language; therefore, the students tend to prefer 
using Bahasa Indonesia to English in class activities.

Nevertheless, all of the teachers in this study contended that the students needed to be introduced to English, as it is the language commonly used in the global arena. At this point, it appears that the teachers were aware of the status of English as a global language, where English acts as the language of business, information, and technology.

I acknowledge there may be some other factors that cause students' low motivation to learn English, which could be related to the teachers themselves. However, I do not have any data regarding this, as I only sought the perceptions of the teachers.

\section{The Teachers' Role}

The participants shared a similar view regarding the role of the teacher in the classroom. They confirmed that in their classes, the teacher was seen as a 'god', the one who knows everything. As a figure, they felt that teachers were treated as very special; everything they said would directly be accepted by the students. These conditions, they said, often happened across all levels of education in Indonesia, even at the university level, where the students are paradoxically expected to be critical and analytical.
Indonesia is one of the countries that has high levels of power distance and collectivism (Kameo, 2007). In this type of country, the students are normally taught to be dependent on others, especially on older people or people with a higher position, such as parents and teachers. Parents and teachers are seen as the most respected people in the community, children or students have been taught to obey them. Due to the high status of the teacher, students are often seen as having a lack of initiative in the class activities (Kameo, 2007). The teachers also added that being quiet is a part of being polite in the students' local culture. As a result, many students considered being quiet as a sign of respect for the teacher.

Some students are shy and quiet. I think... it is a part of the national culture in which the teacher teaches while the students obey everything [what the teacher says], keep silent, only listen and rarely ask a question. (Teacher C, public senior high school)

From the interviews, the teachers in this study seem to agree with the above notion of cultural values. They indicated that good students were those who were quiet and respectful toward the teacher. Additionally, they stated that the students tended to depend on 
the teacher to provide them with the English materials and English environment/exposure.

The first component of this view is quite the contrary to the concept of the role of the teacher in the 2013 curriculum and CA developed by many researchers. The 2013 curriculum urges teacher to actively involve students in the activities during teaching and learning processes. School is part of society which gives well planned educational experience where students can implement what they get from school into real society and utilize society as a learning resource (The Ministry of National Education and Culture, 2013). Therefore, teachers should implement activities that sharpen their critical thinking. The teachers need to create activities that involve the process of scientific approach with based the students as the center of the teaching and learning processes. Further, the concept of CA suggests the teacher performs as a facilitator (Harmer, 2001; Richards, 2005), rather than the source of information, to assist students in the learning processes.

These teachers' perceptions, however, corroborates Ellis' (1996) view that, in EFL settings, teachers act as a source of information as they provide the English environment for the students. In addition, a study in Bangladesh by Chowdhury and Phan Le Ha (2008) reveals that, in this context, some teachers are more comfortable with their role as a source of information and enjoy gaining respect from the students. Furthermore, in Indonesia, "a guru (teacher) is culturally to be digugu (trusted) and ditiru (imitated)" (Dardjowidjojo, 2002, p.122). Therefore, shifting the role to a facilitator may be seen negatively by many teachers.

\section{The Class Size}

The sitting arrangement in our schools, it is hard moving the chairs. So, it is bit difficult... too many students here... I have around 40 students in one class, it is really hard, I prefer having 15-20 students in a class. (Teacher D, Private senior high)

All of the participants explained that working in groups was not always a good idea, since Indonesia still had a common problem, which were big classes. The average number of students in most Indonesian schools is 40 students in each class. The seats are arranged so that students sit in rows and the teacher sits at the front of the class. This condition causes difficulty in making small groups, because the benches or the chairs are difficult to move. I assume that this situation 
influences the teachers' choices of activity to apply in their classrooms. From the questionnaire and interview, the teachers mentioned that pair-works, teacher-questions and student-answers and lectures were the types of activities that were most commonly applied in the. According to them, these activities were considered as the most possible and easiest ones to apply.

The teachers also added that because there were too many students in the class, it was hard for them to monitor the students. Sometimes, they assumed that all of the students understood the lesson by just asking questions to one or two students as representatives to check their understandings. Dardjowidjojo (1997, as cited in Jazadi 2004; 2002) calls this a "pragmatic constraint" where big classes potentially restrict the teacher from performing well in the classroom.

All of the teachers in this study also admitted that cheating and depending on one participant only arose when students did the classroom activities.

There are always only few students who give active participations in class, that's why I often have to ask them to participate in the class activities. (Teacher C, private senior High School)
The teachers stated that this was because they could not check each student individually, due to the large number of students in the class. It seems that the teachers were fully aware that big classes potentially caused problems for them in managing their classrooms. This problem is similar to what Fietchner and Davies (1992) state, namely that a large class which allows six or more students in a group will create a situation where students do not participate fully.

However, the teachers realised that they could not do anything regarding the classroom size. I assume this is because Indonesia is the third most populous country in the world, hence, many young people study at school. A governmental report in 2008 revealed that there were $52,188,520$ students in total studying at primary, secondary and university levels in Indonesia with the average number of 38 students in one class (Badan Penelitian dan Pengembangan - Research and Development Department, 2008). This statistic reflects that it is very difficult for both the government and the schools to reduce the number of students in one class.

\section{The Teachers' Income}

Another concern found from the public institution teachers (Teacher A and Teacher D) is their income. The 
teachers mentioned that their salary was not enough to earn a living. This fact has been one of the problems in Indonesia's education system. Generally, teaching is still regarded to be a poorly paid profession compared to other government employees' professions. Therefore, they explicitly suggested that the government provide a higher salary to the teachers:

The government should give higher salary to the teachers to motivate them; if you can motivate the teachers then the teachers can motivate the students... (laughing). (Teacher D, Public senior high school)

Salaries for public teachers appointed by the government are allocated in the national budget; therefore, their salaries depend heavily on the country's financial resources. As for private teachers, the salary is managed by the institutions themselves, and is usually higher than the salary of the public teachers.

It seems that the insufficient salary affected the teachers' teaching performance, as they said that to overcome this problem they had to teach at two or three different places. The teachers admitted that working in more than one place requires much energy, which influenced the preparation for teaching, such as preparing the materials. Dardjowidjojo
(2002) states that by working in more than one place, the teachers have little time to do academic and extracurricular work, such as preparing the materials and giving attention to each individual student.

\section{The Availability of English Materials}

All of the teachers complained about the lack of English resources in their schools.

We don't have a lot of English reading materials in this school. Most students in Indonesia come from medium to low-level society, so the price of the books is too expensive for them. (Teacher A, public junior high school)

In the interview, these teachers indicated that they relied on particular textbooks for teaching, those prescribed by the government. However, the textbooks cost the students a large amount of money, thus, not all of the students could afford them. As a consequence, a number of students studied without textbooks. This condition, according to these teachers, caused difficulty for them in delivering the materials, because these students would disturb other students to share their books or allow them to borrow the textbooks.

While some students did not have access to textbooks, the teachers, and 
the students, in general, also had difficulty obtaining books written in English. They added that their libraries were not equipped with sufficient English reading books and cassettes for listening activities. This might be because it is very difficult to find books written in English by local publishers. Imported books, on the other hand, are usually available only in big cities, and with high prices; thus, only schools with sufficient funding resources can obtain them.

Another concern remarked by the teachers is the absence of a language laboratory. The secondary school teacher, admitted that her school did not even have this facility, though the rest of the public school teachers said that they did have a language laboratory. However, these teachers stated that the language laboratory did not function well. When I interviewed the senior school teacher at the public school, I had the opportunity to observe their facilities, including the language laboratory. I found that the school had only one language laboratory to be used for 32 classes. It follows that not all of the students had the opportunity to have listening activities in the laboratory.

It should be acknowledged that such facilities significantly help both teachers and students to achieve the learning aims. I believe having these facilities would make it easier for the teachers to implement the concepts of CLT and to have effective and efficient teaching and learning processes. The language lab or audio-visual devices will likely help students practise their English skills. The library should provide students with information related to the teaching materials, the use of which is expected to improve their language skills. This perspective, the importance of facilities, is often neglected when talking about CLT. It might be because theories of CLT emerged from developed countries, where sufficient facilities are taken for granted in their schools. Because of the quality and scarcity of teaching/learning facilities, in developing countries, such as Indonesia, CLT seems very hard to implement.

These problems, by contrast, were not found in the private schools. They explained that their schools had more than one library and language laboratories, which can be used any time they wanted. One teacher, who teaches at a private primary school, stated that her school has sufficient reading materials in English and good support facilities. As for the senior high school teacher, the school also had adequate English resources and facilities. 
In the case study presented, there seems to be a gap between private and public schools. This might be because private institutions are allowed to request funding from students/parents to cover

\section{CONCLUSIONS}

The data revealed that all of the teachers in this study encountered some difficulties in implementing the concepts of CA in regards to the 2013 curriculum in their classrooms. The teachers from all levels of education indicated that they encountered challenges in the following aspects: students' motivation, the role of the teacher, and the availability of the English resources.

The concept of the teacher as a facilitator has also been challenged by the school teachers in this study. They argued that the role of the teacher in the classroom was a source of information, as in EFL settings the teacher was the only one to provide an English environment for the students. Meanwhile, the availability of authentic materials is one aspect that tends to be overlooked. The participants of the study argued that authentic materials are a crucial component for ensuring the effectiveness of teaching and learning process.
This study has revealed some critiques of the implementation of CA in Indonesian education. While the study can only represent the participants' views, it may indeed reflect the views of many other teachers, whose experiences would need to be addressed through professional development. Whether or not these perceptions are widespread would need to be tested in a largerscaled study.

\section{REFERENCES}

Berns, M. (1990). Context of competence: social and cultural considerations in communicative language teaching. New York: Plenum Press.

Brown, D. H. (2007). Principles of language learning and teaching (5th ed.). New York: Pearson Education.

Canale, M. (1983). From communicative competence to communicative language pedagogy. In J. C. Richards \& R. W. Schmidt (Eds.), Language and communication. London: Longman Group Limited, pp.2-27

Canale, M., \& Swain, M. (1980). Approaches to communicative competence.

Chowdhury, R., \& Phan Le Ha. (2008). Reflecting on Western TESOL training and communicative language teaching: Bangladeshi teachers' voices. Asia Pasific Journal of Education, 28(3), pp.305-316

Dardjowidjojo, S. (2002). Academic and nonacademic constraints in the teaching of English in Indonesia. In A. Syahid \& A. Al-Jauhari (Eds.), Bahasa, pendidikan, dan agama: 65 tahun Prof. Dr. Muljanto 
Sumardi. Ciputat: Logos Wacana Ilmu, pp. 117-132).

Ellis, G. (1996). How culturally appropriate is the communicative approach? ELT Journal, 50(3), pp.213-218.

Harmer, J. (2001). The practice of English language teaching (3rd ed.). Edinburgh Gate: Pearson Education Limited.

Hymes, D. (1979). On communicative competence. In C.J. Brumfit \& K. Johnson (Eds.), The communicative approach to language teaching (pp. 5-26). New York: Oxford University Press.

Kameo, R. M. (2007). Critical thinking in the classroom: some cultural constraints. English Edu: Journal of Language Teaching and Research, 7(1), pp.1-13

Kementrian Pendidikan dan Kebudayaan, Dokumen Kurikulum 2013

Kementerian Pendidikan dan Kebudayaan, Paparan Wakil Menteri Pendidikan dan Kebudayaan R.I Bidang Pendidikan: Konsep dan Implementasi Kurikulum 2013, 2014

Li, D. (2000). Teachers' perceived difficulties in introducing the communicative approach in South Korea. In David R. Hall \& A. Hewings (Eds.), Innovation in English language teaching. London: Routledge.
Lie, A. (2007). Educational policy and EFL curriculum in Indonesia: between the commitment to competence and the quest for higher test scores. TEFLIN Journal, 18(1), pp.1-14

Musthafa, B. (2001). Communicative language teaching in Indonesia: issues of theoritical assumptions and challenges in the classroom practice. Journal of Southeast Asian Education(2), pp.2-10.

Segovia, L. P. d., \& Hardison, D. M. (2009). Implementing education reform: EFL teachers' perspectives. ELT Journal, 63(2), pp.154-162

Suparman, U. (2007). The Implementation of competence based curriculum at one of favorite schools in Lampung: a case study. English Edu: Journal of Language Teaching and Research, 7(1), pp.53-70

Suwandi, \& Bharati, D. A. L. (2007). An insight of the teachers' readiness in the KTSP implementation: an overview of the teacher trainer. Paper presented at the TEFLIN International Conference, Jakarta

$\mathrm{Yu}$, L. (2004). Communicative language teaching in China: progress and resistance. ELT Journal, 58(2), pp.194198. 